\title{
A POLÍTICA COMO AUTORITARISMO: O PROJETO COMPARTILHADO DE DONOSO CORTÉS E JAIME BALMES À SOMBRA DE CARL SCHMITT
}

\begin{abstract}
Dr. Roberto Bueno*
Este artigo analisa alguns dos compromissos teóricos do conservadorismo no século XIX espanhol cujo marcado enraizamento teológico católico (Donoso Cortés e Jaime Balmes) e sua ligação com o autoritarismo permitiu que o século XX viesse novamente a interessarse por seus textos, notavelmente pela reinterpretação realizada por Carl Schmitt e que alimentou a reconstrução da teoria da ditadura. Este artigo também contribui para uma análise sobre o quão próxima poderia ser a interpretação do conservadorismo schmittiano do conservadorismo balmesiano, quando é bem conhecido que o primeiro foi um bom leitor do trabalho de Donoso.
\end{abstract}

Palabras clave: Donoso Cortés, conservadorismo, autoritarismo, teologia, Jaime Balmes, Carl Schmitt.

\section{POLITICS AS AUTHORITARIANISM: THE SHARED PROJECT OF DONOSO CORTÉS AND JAIME BALMES IN THE SHADOW OF CARL SCHMITT}

This article analyzes some of the theoretical commitments of Spanish 19th-Century conservatism, whose deep roots in Catholic theological thought (Donoso Cortés and Jaime Balmes) and connections with authoritarianism allowed the 20th Century to again concern itself with its works -visibly in the reinterpretation realized by Carl Schmitt, which fuels the reconstruction of the theory of dictatorship. This article also contributes to analyze how close the interpretation of Schmittian conservatism might be to the Balmesian one, since it is well-known that the former was a very good reader of Donoso's work.

Keywords: Donoso Cortés, conservatism, authoritarianism, theology, Jaime Balmes, Carl Schmitt.

\footnotetext{
* Universidade Federal de Uberlândia, Minas Gerais, Brasil. Correo electrónico: rbueno_@hotmail.com.
} 

$-$

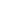




\section{Diálogo sobre o conservadorismo: Donoso Cortés e Jaime Balmes}

UM DOS COMPATRIOTAS DE DONOSO CORTÉS QUE OPERA EM SUA mesma linha conservadora e católica é, indubitavelmente, Jaime Balmes (1810-1848), autores que mantém paralelo desenhado inicialmente por Menéndez Pelayo'. Pouco recepcionado no Brasil mais também recebendo críticas quando a sua pouca atenção no mundo filosófico espanhol ${ }^{2}$, o autor interessa a esta dissertação na medida em que seu texto é elaborado com o mesmo viés conservador e monarquista de Donoso, ademais de profundamente comprometido seriamente com um humanismo aberto à transcendência ${ }^{3}$, singularmente conectado com o catolicismo, ao tempo em que também permanece atento às vicissitudes sociopolíticas e aos debates teológicos daquele período.

Neste sentido é certo dizer que, muito embora Donoso não tenha mantido contato direto com Balmes, que são autores que ocupam-se dos mesmos objetos segundo ótica analítica similar. Já em seu tempo o Duque de Valmy apresentara Donoso como um pensador próximo a Balmes ${ }^{4}$ e isto é algo que o texto de Donoso confirma ao dizer que "[...] Pío IX ha sido el hombre de quien Dios ha querido servirse para desengañar al mundo por lo que respecta a su Iglesia [...]"5. Donoso retoma aqui a ideia do pontificado como a força terrena capaz de executar o plano divino na Terra. Neste aspecto também converge Balmes, permitindo traçar um paralelo entre ambos como intelectuais comprometidos tanto política quanto ideologicamente com o espectro filosófico, latu sensu, de direita, com o tradicionalismo ideológico e o conservadorismo autoritário ${ }^{6}$.

1 Cfr. Menéndez Pelayo, Marcelino, Historia de los heterodoxos españoles, $4^{\mathrm{a}}$ ed., II tomos, B.A.C., Madrid, 1987.

2 López Medina é um dos autores que chama a atenção para o fato de que Balmes não recebe a devida atenção nem mesmo sequer no mundo hispânico do qual é natural. O autor destaca a importância da filosofia balmesiana que oferece fundamentos novos para uma filosofia realista, a qual "[...] es de una importancia tal que debería ser mejor conocida y discutida por el estamento filosófico español”. López Medina, Emilio, "Balmes: La opción realista", Actas del IV Congreso Internacional de la S.I.T.A., Tomo III, Comunicaciones, Publicaciones Obra Social y Cultural Cajasur, Córdoba, 1999, pp. 1485-1491, p. 1491.

3 Cfr. Roca, Dionisio, "Humanismo, progreso y trascendencia en el pensamiento balmesiano", Actas del IV Congreso Internacional de la S.I.T.A., Tomo IV, Comunicaciones, pp. 1949-1957, p. 1949. Roca destaca que dentre os méritos de Balmes encontra-se "[...] su convicción de la necesidad de una escala de valores para reconducir los pasos del hombre hacia los fines que le son propios". Idem.

4 Cfr. Valmy, Duque De, “Al Sr. Donoso”, París, 22 de septiembre de 1850, em Donoso Cortés, Juan, Obras de Don Juan Donoso Cortés, dirección y prólogo de Don Juan Manuel Orti y Lara, Vol. II, Casa Editorial de San Francisco de Sales, Madrid, 1904, pp. 331-333, p. 327.

5 Donoso Cortés, Juan, "Carta de Donoso Cortés al Señor Duque de Valmy”, Madrid, 20 de julio de 1850, Obras de Don Juan Donoso Cortés, Casa Editorial de San Francisco de Sales, Madrid, 1904, pp. 328-330, p. 329.

6 Cfr. González Cuevas, Pedro Carlos, El pensamiento politico de la derecha española en el siglo XX. De la crisis de la Restauración al Estado de partidos (1898-2000), Tecnos, Madrid, 2005, p. 25. Por intermédio destas análises objetivamos, em segundo plano, colocar em perspectiva se estas reflexões podem, em alguma medida, antecipar, em alguma medida, a filosofia política de corte autoritário-ditatorial schmittiana emergente na primeira quadra do século XX. 
Jaime Luciano Balmes (1809-1848) foi filósofo e clérigo espanhol de origem catalã cuja vida, curiosamente, foi tão breve quanto a de Donoso Cortés. Intelectual dedicado ao (neo) escolasticismo, escola que em seu momento gozou de grande prestígio no mundo filosófico espanhol igualmente desfrutou de excelente reputação nos meios conservadores. Não obstante, várias são as posições que procuram estabelecer paralelo entre sua obra e a de Donoso, hipótese da qual o catalão emerge ocupando posição de notável secundariedade 7 . Por outro lado, em Balmes encontra-se uma aproximação ao político e à realidade espanhola em torno a dois eixos principais, a saber, a religião e a monarquia ${ }^{8}$. Tanto Balmes assim como toda a tradição conservadora espanhola, a qual pertence Donoso, ancora e encontrará no argumento religioso o elemento definidor e identificador do caráter nacional espanhol, que, posteriormente, tão ingente papel desempenharia na edificação e manutenção não só da ditadura franquista espanhola como também de sua predecessora com Primo de Rivera ${ }^{10}$.

Este é período em que as forças intelectuais do regime franquista começaram a ser arregimentadas para combater na Guerra Civil espanhola contra as forças republicanas, compostas por uma miríade de grupos ideológicos de esquerda. Seus valores, necessariamente, vislumbravam ao liberalismo como um necessário adversário a combater ${ }^{11}$. Ainda assim, não carece de interesse ressaltar o papel de destaque exercido por Balmes no pensamento conservador colombiano no século $\mathrm{XIX}^{12}$. Uma breve retomada das conexões católico-conservadoras que se estabelecem entre os textos de Donoso Cortés e Balmes permite observar o quão profunda e intensamente a argumentação schmittiana pode apresentar-se nesta tradição em seus esforços por angariar apoio conservador às suas teses teológico-políticas ${ }^{13}$.

Indica Galindo Herrero que há um amplo grupo de comentaristas que ao explorar as relações entre Donoso e Balmes, dentre os quais José María García Escudero, que apre-

7 Vid. Menéndez Pelayo, Marcelino, Dos palabras sobre el centenário de Balmes. Ensayos de crítica filosófica, Aldus, Santander, 1948. Neste sentido, para uma aproximação de Menéndez Pelayo e o conservadorismo donosiano por intermédio das senhas do catolicismo, vid. Pellistrand, Benoît, "Catolicismo e identidad nacional en España en el siglo XIX: un discurso histórico de Donoso Cortés a Menéndez Pelayo", Religión y Sociedad en España: (siglos XIX y XX): Seminario celebrado en la Casa de Velázquez (1994-1995), coord. por Paul Aubert, 2002, pp. 91-120.

8 Cfr. Perfecto García, Miguel Ángel, "O pensamento antiliberal espanhol: intelectuais e políticos antiliberais na Espanha do primeiro terço do século XX”, em Limoncic, Flávio, e Martinho, Francisco Carlos Palomanes (org.), Os intelectuais do antiliberalismo. Projetos e políticas para outras modernidades, Civilização Brasileira, Rio de Janeiro, 2010, pp. 439-476, p. 449.

9 Cfr. ibidem, p. 450.

10 Primo de Rivera foi general catalão que sob pretexto de combater o governo liberal de então, procede ao seu combate em 1923, evento que redundaria em uma ditadura que se prolongaria de 1923 a 1930.

11 Sobre alguns detalhes da política, da ditadura e do caudillismo em Primo de Rivera, vid. ReIg Tapia, Alberto, "Aproximación a la teoría del caudillaje en Francisco Javier Conde", Revista de Estudios Politicos (Nueva Época), Núm. 69, julio-septiembre, 1990, pp. 61-81.

12 Vid. Villar Borda, Luis, Donoso Cortés y Carl Schmitt, Universidad Externado de Colombia, Bogotá, 2006, p. $106,109-174$.

13 Para uma breve mais substanciosa leitura sobre Balmes e seu período encontra-se o texto de Urigüen. Vid. UrigüEn, Begoña, Orígenes y evolución de la derecha española: el neo-catolicismo, Centro de Estudios Históricos / C.S.I.C., Madrid, 1986, pp. 65-74. 
sentam Balmes como uma mera correção de Donoso ${ }^{14}$, mas também como um autor de "[...] primeirísima fila [...]"15, dono de um "[...] pensamiento fulgurante de [...] profunda y brillante personalidad [...]"16. Ao lado de Donoso, Balmes é reputado como o par de intelectuais-eixo para bem compreender o século $\mathrm{XIX}^{17}$ espanhol em suas incidências teológico-conservadoras.

Em Balmes podemos apresentar sua ideia de poder em paralelo com a de Donoso, a saber, como um duo de pensadores da filosofia política que orientam seu trabalho pelas bases teológicas do catolicismo. Esta é uma tradição sempre presente nos passos do Marquês de Valdegamas, e que aproximam-se, como sugere Begoña Urigüen, a estes dois membros de uma escola política que tem sua origem no catolicismo ${ }^{18}$.

Comentaristas como Menéndez Pelayo assinalam que a proximidade entre ambos intelectuais espanhóis encontram-se tão somente na defesa dos valores do catolicismo, pois, em tudo o mais mostrariam uma natureza realmente muito diversa ${ }^{19}$. Muito embora não tenha mantido contato direto com Balmes, senão já ao final de sua vida, há notícia de contato teórico com Donoso, algo que foi expressamente mencionado em seu texto, logo ao tornar-se sabedor do falecimento de Balmes. Conforme viemos insistindo, é correto apontar que há proximidades teóricas relevantes entre os trabalhos do filósofo extremenho e do barcelonês, aspectos estes que visamos investigar neste capítulo ao testar o grau de consistência da argumentação teológico-política de Donoso com a de Balmes. Esta tarefa pode ser cumprida quando tomamos por fio condutor alguns dos temas teológicos centrais, a saber, o mal, o pecado, a salvação e a intervenção da divindade incluídos, assim como quais são as suas possíveis aplicações à política.

Com não menor ênfase, segundo aponta Escudero, Balmes é autor que sublinha a importância do elemento teológico para refletir sobre o político ${ }^{20}$, seguindo as linhas orientativas de um movimento que se descola da teoria maquiaveliana e concebe o político fora de quaisquer interferências da moralidade e que, por conseguinte, atingira as pretensões da teologia em matéria política. Chegado o século XIX, Balmes proporá que a “[...] política debía impregnarse cada día más de aquel espíritu cristiano que había de dar fuerza, y

14 Cfr. Galindo Herrero, Santiago, "Donoso Cortés en su paralelo con Balmes y Pastor Díaz", Revista de Estudios Políticos, No. 69, 1953, pp. 111-140, p. 114.

15 Prieto Escudero, Germán, "Balmes o la prioridad de lo sociorreligioso sobre lo políticoeconómico", Revista de Estudios Políticos, No. 182, 1972, pp. 159-180, p. 161.

16 Ibidem, p. 166.

17 Cfr. Macías López, Joaquín, "Balmes y Donoso Cortés ante la política española en el siglo XIX”, El Catoblepas, No. 105, Noviembre, 2010, pp. 1-14, p. 1. Disponível em: http://nodulo.org/ec/2010/n105p14.htm. Acessado em: 27 de abril de 2011.

18 Cfr. Fornés Murciano, Antonio, "Providencialismo, decisionismo y pesimismo antropológico. Influencia de Joseph de Maistre en la teología política de Donoso Cortés”, Hispania Sacra, Vol. LXIII, 127, enero-junio, 2011, pp. 235-260, p. 239.

19 Cfr. Galindo Herrero, S., op. cit., p. 116.

20 Cfr. Prieto Escudero, G., op. cit., p. 173. 
servir de guía, en combate contra doctrinas demoledoras de lo ético" ${ }^{21}$. A ideia balmesiana de fundo era, portanto, que a política haveria de encontrar um padrão ou código moral de fundo capaz de orientar-lhe, segundo uma ideia de que o bem haverá de triunfar por intermédio desta estrutura moral calcada nos perfeitos padrões da teologia da Igreja Católica Apostólica Romana.

Muito embora toda a diferença de fundo eventualmente detectável entre ambos, esta resta de todo neutralizada por similares esforços intelectuais em prol da reforma social, o que visam realizar por intermédio da intervenção de Deus, embora a subsistência de divergências pessoais inferiores ${ }^{22}$. Encontra-se um ponto de convergência essencial entre Donoso e Balmes na detecção de comuns opositores, a saber, o racionalismo liberal, o socialismo ateu ${ }^{23}$ e as versões do filosofismo francês, a quem duramente reprovavam em plena temporada em que pontificavam a esperança da regeneração moral do homem por via da pura ação humana e não pela intervenção redentora da divindade. Galindo Herrero chama a atenção para o fato de que Balmes intervém como um genuíno restaurador do catolicismo no âmbito da filosofia espanhola e, por outro lado, a Donoso lhe reprova pelo seu caráter exacerbadamente tradicionalista ${ }^{24}$.

Ademais da comum atividade literária ${ }^{25}$ a proximidade entre Donoso e Balmes pode também ser desenhada tomando como referência a análise do trabalho teológico e político de Pio IX, tornado personagem central para pensar o político em Donoso em sua dimensão temporal, posto que capaz não apenas de representar a vontade divina na Terra como de empreender exitosamente o seu plano por intermédio de seu preposto, o Papa e sua instituição eclesial, valendo-se todos de seus grupos amigos ${ }^{26}$. A este respeito, por exemplo, em carta endereçada a Donoso Cortés, o Duque de Valmy chama a atenção para que Pío IX não reforçaria o papel dos liberais, senão exatamente o contrário. Segundo o autor, o Papa haveria de prosseguir em suas reformas " [...] en el sentido y manera que usted ha indicado, con el fin de romper las cadenas de la Iglesia, y de salvar al mundo de la nueva servidumbre que le impondría la filosofía anticatólica”.

Balmes é autor que embora sem referência direta, escreve em reforço do vigor da argumentação conservadora e teológica donosiana, da qual viria a servir-se o pensamento

21 Idem.

22 Galindo Herrero, S., op. cit., pp. 116-117.

23 A este respeito destaca Galindo Herrero que "Balmes atacó al socialismo científico y al utópico, y aun cuando arrojó también su lanza en alguna ocasión contra el revolucionario -especialmente contra Proudhon- [...]” (ibidem, p. 139), e nisto, por certo, também aproxima-se de Balmes.

24 Cfr. ibidem, p. 116.

25 Neste aspecto a opinião de Menéndez Pelayo é, em extremo, desfavorável ao barcelonês, pois indica que "Comparado con el estilo regio de Donoso, Balmes parece un mediocre escritor; pero ofrece, en cambio, un más sólido realismo, una formación filosófica más segura y esa ecuanimidad serena que a la larga fructifica mejor". (apud Corts Grau, José, "Perfil actual de Donoso Cortés", Revista de Estudios Políticos, Nos. 19-20, 1945, pp. 74-118, p. 84, disponível em http://www.cepc.es/rap/Publicaciones/Revistas/2 /REP_019-020_084.pdf. Acesso em 03 out. 2009.

26 Cfr. Valmy, DuQue De, op.cit., p. 333. 
autoritário do século $\mathrm{XX}$ aqui representada por $\mathrm{Schmitt}^{27}$ com a finalidade de deslocar o eixo de legitimação do poder e da autoridade para esferas outras distantes e inatingíveis ao controle do povo.

É importante considerar que embora o trabalho de Balmes não tenha sido citado diretamente por Donoso sugerimos ser clara a convergência temática da Donoso por força de um conjunto de referências que podem ser resumidas, se necessário, em uma fidelíssima crença no valor do catolicismo romano e da fé também compartilhada em grau intenso. Não pode ser desconsiderado o conjunto do movimento de aproximação do catolicismo, mais do que apenas e tão somente o elemento religioso, ao político. Estas considerações permitem-nos sugerir que, muito embora sem ser citado diretamente, o trabalho de Balmes também representa uma contribuição à formação da cultura autoritária da segunda metade do século XIX e de sua consolidação já entrado o século XX, havendo quem sugira que Balmes também faz-se presente em Schmitt por intermédio do conservadorismo donosiano ${ }^{28}$, e esta é é ${ }^{29}$ definitivamente, uma ideia escassíssimamente explorada pela literatura especializada e que aqui encontrará espaço.

Um dos aspectos em que a leitura de Balmes suscita claros pontos de convergência com a teologia especulativa de Donoso é quando o autor se mostra acidamente crítico da natureza das revoluções, ao passo em que intensamente temeroso quanto aos seus efeitos. Isto permitirá que Balmes descrevesse os processos revolucionários como “[...] enfermedades agudas que consigo traen exaltación, fiebre, delirio" ${ }^{30}$, referência integralmente compatível com a descrição das revoluções também realizada por Donoso quando delas dizia que tratava-se de movimentos promotores da corrupção e da perversão das ideias ${ }^{31}$. A proximidade entre Donoso e Balmes quando temos em meio a matéria revolucionária foi também assinalada por Menéndez Pelayo, quando diz que:

27 Conforme mencionado ainda na introdução a este trabalho, nos interessa explorar nesta dissertação, ainda quando superficialmente algumas das fontes que inspiram a boa avaliação que deles realiza Schmitt em sua composição teológica do político. Sugerimos que esta breve aproximação a pensadores como Primo de Rivera e Balmes, por exemplo, permitirá que leiamos com mais profundidade o sentido, o vigor e a intensidade com que o pensamento conservador concebe o poder, e como isto pode ser realmente útil para pensar o sentido da soberania, do poder e da ditadura em teorias que apontam para alternativas políticas fechadas, como é o caso de Schmitt.

28 Mesmo sendo assunto pouco explorado, entre nós há um trabalho de mestrado na área de História cujo foco é o conservadorismo espanhol e, especificamente toma como objeto as relações entre Donoso Cortés, Jaime Balmes mas também De Maistre e De Bonald, tendo como tema transversal do trabalho a política e a religião. Vid. Pavani, Roney Marcos, Repensando o conservadorismo católico: politica, religião e história em Juan Donoso Cortés, Dissertação de Mestrado em História Social das Relações Políticas, Dissertação apresentada no Centro de Ciências Humanas e Naturais do Programa de Pós-Graduação em História da Universidade Federal do Espírito Santo, 2010, disponível em http://www.ufes.br/ppghis/Documentos/2008/Roney\%20Marcos\%20Pavani-\%20 Turma\%202008\%20DE FESA.pdf. Acesso em 15. Mar.2011.

29 Vid. Rodríguez CaAmaño, Manuel, "Presentación. Jaime Balmes y las Ciencias Sociales", Reis. Revista Española de Investigaciones Sociológicas, No. 82, 1998, pp. 285-290, p. 285. Rodríguez Caamaño é expressivo a respeito das diversas fontes proveitosa e influentemente lidas por Balmes, que variaram de Santo Tomás a Kant, de Descartes e Comte a De Maistre, De Bonald, Lamennais, Rousseau, Guizot e Owen (cfr. idem). O autor traça uma visão não tão conservadora de Balmes como habitualmente encontra-se, contraponto que torna recomendável o texto.

30 Balmes, Jaime, Obras Completas. Escritos Políticos, Tomo VI, B.A.C., Madrid, 1950, p. 358. 
Dios los suscitó en el instante de la tremenda crisis, en la aurora de la revolución, y la semilla que ellos esparcieron no toda cayó en terreno estéril e infecundo [...]. Ellos dieron el pan de vida intelectual a una generación próxima a caer en la barbarie... no escribieron para el día de hoy, fiaron poco de personas ni de sistemas; todo lo esperaron de la regeneración moral [...] del espíritu cristiano en la vida ${ }^{32}$.

O espírito revolucionário vai acompanhado de um inesperado vetor teológico em De Maistre, ao menos a partir do momento em que, já no exílio, convive com padres católicos, capazes de lhe convencer de que mesmo todo o sangue derramado não fugia ao plano da história traçado por Deus. Donoso Cortés sempre manteve-se atento ao processo revolucionário francês, muito embora nem sempre com a mesma perspectiva analítica. Donoso é apoiador e compartilhador de suas boas expectativas e, em outros momentos, em especial, o de sua conhecida conversão, passa a criticá-la por sua conexão com a proliferação de constituições políticas marcadas por um profundo poder demagógico ${ }^{33}$ calçado no povo. Sua crítica também está marcada pelo profundo anticlericalismo dos movimentos revolucionários e, por certo, devido a todas as nefastas consequências que isto aportaria às organizações sociais. Donoso também chama a atenção para o fato de que o mundo não havia sido jamais palco de espetáculo deste naipe:

[...] y si pudiera haber algo absolutamente nuevo debajo del sol, lo sería, sin duda, el espectáculo que ofrece la Francia, compuesta de monárquicos que no pueden fundar una Monarquí, y oprimida bajo el peso de una República que para su defensa no tiene republicanos ${ }^{34}$.

Havia muito a lamentar não apenas pelo ocaso dos regimes monárquicos mais também, e, quiçá, principalmente, pelo conjunto de valores que entronizavam e, por toda a simbologia de poder que enfeixava. Destituída de um regime político afim com as preferências de seus indivíduos, ainda assim diz Donoso que a França poderia ser vista como um contraexemplo a ser bastante bem observado, pois:

31 Cfr. Donoso CoRTÉs, Juan, "Discurso sobre la situación de España", pronunciado en el Congreso el 30 de diciembre de 1850, al discutirse el proyecto de autorización al Gobierno para plantear los presupuestos del siguiente año, Obras de Don Juan Donoso Cortés, Casa Editorial de San Francisco de Sales, Madrid, 1904, pp. 183-214, p. 205. Para um exame mais minucioso sobre as revoluções remetemos o leitor ao capítulo XIII.

32 Apud Martínez-Sicluna, Consuelo, "Donoso Cortés: La cuestión vital de España”, Anales de la Fundación Elías de Tejada, Año XVI, 2010, pp. 161-169, p. 163, disponível em http://www.fundacioneliasdetejada.org/ Documentacion/Anales/PDF\%20ANALES\%2016/ANA16-P-161-169.pdf. Acessado em: 20 de setembro de 2011.

33 Cfr. Donoso Cortés, Juan, "Carta ao Director de la 'Revue des Deux Mondes', en refutación de un artículo de M. Alberto de Broglie”, París, 15 de noviembre de 1852, Obras de Don Juan Donoso Cortés, Casa Editorial de San Francisco de Sales, Madrid, 1904, pp. 411-437, p. 421.

34 Donoso Cortés, Juan, “Carta de Donoso Cortés", París, 15 de julio de 1851, Obras de Don Juan Donoso Cortés, Casa Editorial de San Francisco de Sales, Madrid, 1904, pp. 476-480, p. 479. 


\begin{abstract}
[...] Francia puede servirnos de lección y de modelo. Mientras que la fiebre revolucionaria la postró exánime y convulsa en un lecho de dolores, todos los partidos que se sucedieron en el mando [...] la dotaron sucesivamente de varias Constituciones inmortales, que llegaron a su ocaso sin atravesar su cenit ${ }^{35}$.
\end{abstract}

O tom desta crítica donosiana à realidade política da França não perderia a constância. $\mathrm{O}$ autor manteria os termos críticos que opõe-se ferreamente às virtudes teórico-políticas revolucionárias de corte republicano que o movimento francês continha e que se preocupava em disseminar. Donoso Cortés destaca as profundas instabilidades políticas e institucionais causadas pela Revolução como males em si mesmos, algo que restava bem exemplificada pela França, tão convulsionada em um leito de graves dores. Nenhuma destas moléstias era sequer remediável pelos textos constitucionais humanos, tão carregados de altas pretensões quanto destituídos de possibilidade de realização. É premissa teórica de tais processos que, para ser exitosos, hão de supor um amplo ataque capaz de causar à tradição ${ }^{36}$.

Donoso Cortés reputa que os ataques endereçados a tradição era enfrentamento à própria representação da verdade ${ }^{37}$ que não poderia ser construída mas tão somente observada após longa experienciação coletiva de resultados compartilhados. Isto declaradamente significaria um limite para o desenvolvimento de projetos vislumbrados pela razão anticlerical. Muitos destes projetos não sofrem menoscabo por força de mau planejamento nem de falta de inspiração em sérios propósitos. A inviabilização empírica porta todo o desvalor que o conservadorismo atribui aos projetos ousados, que rompem com o socialmente estabelecido valendo-se apenas das pretensiosas aspirações da razão humana. Por trás desta argumentação subjaz, implícito, uma forte ponderação que denota uma poderosa Weltanschauung, a saber, que há toda uma série de determinações e de ordens às quais

35 Donoso Cortés, Juan, Obras Completas de Donoso Cortés. Tomo I, B.A.C., Madrid, 1946, p. 323.

36 Um aspecto importante é delimitar o campo do que entenderemos aqui como tradição. Neste particular, especialmente sugestiva parece a abordagem de Schramm ao propor a compreensão do conceito de tradição na Espanha da primeira metade do século XIX como informada pelos seguintes elementos: " $1^{\circ}$ Tomar partido por la monarquía, mas a mi entender, no por la monarquía absoluta en el sentido europeo del término, toda vez que, en el fondo, esta forma de monarquía absoluta jamás existió en España; $2^{\circ}$ Oponerse a la soberanía popular y a todas las construcciones resultantes de la misma, tales como, vervi gratia, el concepto revolucionario de libertad; $3^{\circ}$ Oponerse a la revolución, por cuanto es un producto de esta soberanía popular, y, a la vez, anticristiana y anticlerical; $4^{\circ}$ Defensa de la religión heredada y de las relaciones históricas entre el Estado y la Iglesia, así como afirmación del influjo del cristianismo sobre la cultura; $5^{\circ}$ Defensa en general del peculiar estilo de vida español, que estaba mucho menos secularizado que las formas de vida de los demás países de la Europa occidental. En relación con esto, defensa también de una determinada concepción del orden; $6^{\circ}$ Defensa de los antiguos derechos forales de las regiones y de los fueros municipales, como matriz anticentrista de este pensamiento tradicionalista". Schramm, Edmund, Donoso Cortés, ejemplo del pensamiento de la tradición. Colección O Crece o Muere, no. 28, $2^{\text {a }}$ edición, Ryvadeneira, Madrid, 1961, pp. 14-15.

37 Cfr. Donoso CoRTés, Juan, Ensayo sobre el catolicismo, liberalismo y socialismo, Editorial Americalee, Buenos Aires, 1943, p. 141. 
o homem simplesmente deve aceitar ${ }^{38}$, posição de resignação cujo translado ao político é capaz de produzir importante impactação.

\section{A teologia política face ao projeto liberal}

Tomar o liberalismo como um dos alvos conexos a esta crítica à Revolução Francesa é um dos movimentos do conservadorismo donoso-balmesiano que abre portas aos argumentos políticos de corte autoritário-ditatoriais do século XIX. Uma das vias para o aprofundamento desta tarefa foi a sua crítica a estratégia de desentronizar a verdade eterna e universal, divina, para entronizar outra figura sob as mesmas vestes divinas, a saber, a razão humana. Donoso atribui a argumentação revolucionária o reconhecimento de que o único mal no mundo é derivado do abandono das instituições herdadas do passado profundo ${ }^{39}$. Segundo os pressupostos donosianos resta claro que o campo de luta ideológica fica delimitado, e que as forças tradicionais do passado eram aquelas contra as quais haveria de ser empregados os mais intensos esforços no sentido de suprimi-las.

Um dos principais focos destes esforços residiria nas manifestações tradicionais das formas de organização do poder político e, em suma, do governo. Alguns destes louváveis esforços progressistas orientam as revoluções mas, ao contrário das melhorias e avanços relativamente às obscuridades do passado, elas se tornam tão temidas por Donoso tão grande o descompasso entre as promessas e as suas realizações, algo que se agrava pelo fato de que o ataque às tradições envolve o aprofundamento de seu caráter notavelmente anticlerical.

A instabilidade das instituições, contida na essência da ameaça revolucionária, ganha maior evidência pelas sucessivas e fracassadas tentativas dos regimes revolucionários em instaurar e manter a vigência das Constituições. Estas revelaram-se empiricamente dotadas de caráter meramente destituídas de caráter permanente mas, antes, pela transitoriedade. Estes documentos legais instituem a provisoriedade como regra, e vem a conhecer o seu ocaso antes mesmo de alcançar o seu apogeu. Naquela quadra da história, Donoso Cortés atenta para estas contínuas articulações da cultura jurídico-político liberal que corroíam a tradição política medieval e monárquica, o que lhe permitiria aspirar a consecução de um projeto que o autor reputava de finalização inviável, ademais de indesejável, devido aos seus princípios em absoluto desvinculados da teologia do catolicismo.

38 Cfr. Schramm, E., op. cit., p. 34. Segundo Donoso Cortés é mesmo certo que a vontade humana é instável. Contudo, embora adotando este ponto de partida, isto não lhe impede de endereçar críticas ao liberalismo que parte deste pressuposto para, na sequência, emular um sistema político de equilíbrio, não obstante, este sistema seria apenas transitório, em aberta discrepância a pretensão de uma estabilidade perfeita que resultasse em uma ordem comparável aquela introduzida pela divindade. Donoso sugere, portanto, que a superação da instabilidade que marca o querer humano que para resolvê-lo em um querer de equilíbrio perfeito de todo modo necessário considerar que isto é apenas alcançável pela união na divindade.

39 Donoso Cortés, J., Ensayo..., op. cit., p. 187. 
Para Donoso Cortês a inviabilidade do projeto liberal que habita o âmago de algumas versões das filosofias revolucionárias. Donoso calibra a sua posição, refratária aqueles que visam edificar a sociedade em sua genuína verdade por intermédio de um longo e pacífico processo histórico ${ }^{40}$, e não tocada pela graça. Para Donoso, é esta última que representa a mais intensa e profunda possibilidade de real transformação na história, posto que substitui a pura repressão política pela sofisticada e mais eficaz repressão de tipo religiosa ${ }^{41}$, que age diretamente sobre a psiquê humana. De certo modo, trata-se da opressão humana por meio do recurso ao poder por um magnífico redimensionamento do campo moral que obriga e vincula o homem desde dentro. Portanto, o processo em curso no pensamento donosiano indica o percurso de uma forma de pensar o direito que parte da heteronomia (determinada juridicamente) para uma versão da autonomia (determinada teologicamente).

Todo o conjunto de profundas reformas sociopolíticas propostas aparece para Donoso Cortés como componente de uma séria ameaça ao catolicismo e suas injunções políticas. Estas ameaças visam inverter uma perfeita e estável ordem universal calcada nas tradições, as quais encontram-se ancoradas em uma muito clara e insofismável ordenação teológica de fundo das formas de vida daqueles que, como pretensos edificadores, pretendem alterar o que o longo curso da história instituiu.

Face a uma ameaça ou transgressão da ordem Donoso Cortés depara-se com a possibilidade de restauração e da salvação das sociedades humanas na situação de dependência da intervenção da divindade, posto que confirmadas o fato de que "[...] superioridad de la Iglesia sobre las sociedades civiles es una cosa conforme á la recta razón, la cual nos enseña que lo sobrenatural es sobre lo natural, y lo divino sobre lo humano [...]"42. As sociedades civis encontram-se em plano inferior à ordem eclesial, e esta, segundo os seus fundamentos transcendentais, é que pode orientar estas organizações coletivas humanas no sentido de suplantar as suas crises. Desta forma encontra-se posta a condição de possibilidade para a intervenção redentora ainda no plano temporal, mesmo quando Donoso mostre-se mais do que cético quanto a esta possibilidade.

Quanto ao caráter pacífico de que se valeria a divindade para operar a história no plano terrestre conforme sugere Schramm, restam algumas dúvidas. Trata-se de que é presente em Donoso Cortés a ideia de que até mesmo as revoluções possuem um caráter depurador, ideia que, por certo, repete-se em uma de suas grandes influências, o savoiano De Maistre e que, ao operar tal depuração, alguma dose de violência não seria prática incompatível. Aparece em De Maistre e em Donoso uma clara condenação às práticas sanguinolentas revolucionárias $^{43}$, mas isto é algo que ocorre em paralelo e, talvez paradoxalmente, a crença

40 Cfr. Schramm, E., op. cit., p. 20.

41 Cfr. ibidem, p. 28.

42 Donoso Cortés, Juan, "Carta al eminentísimo señor Cardenal Fornari sobre el principio generador de los más graves errores de nuestros días", París, 19 de Junio de 1852, em Obras de Don Juan Donoso Cortés, Casa Editorial de San Francisco de Sales, Madrid, 1904, pp. 385-409, p. 407.

43 Cfr. De Maistre, Joseph, Maistre: Considerations on France, Cambridge University Press, Cambridge, 1994, p. 48. 
de que as revoluções podem representar o desígnio divino para depurar o pecado na Terra, aplicando castigos que encontram paralelos bíblicos como, por exemplo, na ocorrência do dilúvio precedido da extensão insuportável do pecado no mundo. No Gênesis é clara a referência a este propósito divino de eliminar o mal do mundo por meio de duro castigo:

5. O senhor viu que a maldade dos homens era grande na terra, e que todos os pensamentos de seu coração estavam continuamente voltados para o mal. 6. O Senhor arrependeu-se de ter criado o homem na terra, e teve o coração ferido de intima dor. 7. E disse: "Exterminarei da superfície da terra o homem que criei, e com ele os animais, os répteis e as aves do céu, porque eu me arrependo de tê-los criado. (BíBliA SAGRAdA, Gênesis, 6, 5-7).

Esta é uma ideia logo reafirmada nos trechos subseqüentes do Gênesis, em que é reforçado que a corrupção pode ser remediada pela violência como recurso legítimo a ser empregado pela própria divindade. Trata-se de uma versão do mal (violência) empregado por Deus para combater o mal produzido pelo homem na Terra que, por divino o instrumento, estaria apto a produzir o bem. Segundo a versão do Gênesis encontramos que:

11. A terra corrompia-se diante de Deus e enchia-se de violência. 12. Deus olhou para a terra e viu que ela estava corrompida [...]. 13. Então Deus disse a Noé: "Eis chegado o fim de toda a criatura diante de mim, pois eles encheram a terra de violência. Vou exterminá-los juntamente com a terra. 14. Faze para ti uma arca de madeira resinosa [...]”" (BíBliA SAGRADA, Gênesis, 6, 11-14).

Neste trecho encontramos uma possível leitura para a interpretação do plano divino como composto de grandes castigos, à semelhança do dilúvio, e que, naquela quadra histórica de final do século XVIII e meados do século XIX, poderiam encontrar sua nova interpretação na realização das revoluções. Estas, embora pudessem ser atacadas por Donoso, assim como o fez De Maistre, também poderiam constar do plano divino redentor, à semelhança do citado trecho do Gênesis.

Algo que os pretensiosos programas revolucionários põe em causa e direcionar as sociedades por rumos todavia pouco conhecidos ou, mesmo, inusitados, e, não raro, recheados de esperanças magnificentes no porvir. Trata-se de expectativa de institucionalização de ilusões projetadas sobre a forma regimental dos governos representativos, contra as experiências impositivas do sobrenatural. Contudo, os sistemas representativos pouco ou nada mais podem do que expressar toda a amplitude da debilidade humana, uma vez que são governos calcados na virtude da deliberação dialógica, e não na revelação da indiscutível verdade divina. Este seu caráter de genuína encontra sua positiva representação na 
tradição configurada pela construção do conceito de civilização católica, a qual procura distanciar-se do modelo representativo-dialógico para basear-se na imposição da verdade por outorga divina.

É neste sentido que Donoso Cortés destaca a superveniência de um suposto grave problema dos governos representativos, qual seja, o de que eles não podem absorver em suas ações, realmente

[...] la personalidad de los individuos que, gozando de una vida propia, se mueven independientemente de su esfera. Los individuos, como el Gobierno, obran, y obran como seres inteligentes y libres ${ }^{44}$.

Para um Donoso Cortés que clama pela unidade como um dos elementos de sua boa civilização católica, desde logo, o governo que acolha as discrepâncias de personalidades de seus cidadãos refletirá no âmbito do político a uma indesejável situação de instabilidade. Esta conformação presente nos sistemas representativos será para Donoso, necessariamente, alvo de críticas.

Os governos agem como representantes perfeitos que, efetivamente, não podem sequer almejar ser. A unificação do poder de representar aos indivíduos encontra-se tão somente na esfera superior, ou seja, da própria divindade, que reúne a pluralidade em sua magnífica unicidade. Contudo, no plano humano, há uma independência completa de ações que encontra-se muito distante da verdadeira liberdade, como veremos já a partir do tópico seguinte.

\section{Consideraçôes Finais}

Em Donoso Cortés é detectável inclusive um suposto caráter satânico ${ }^{45}$ no âmago do movimento revolucionário ${ }^{46}$. Esta característica estaria em diversos aspectos das ações políticas da transição do século XVIII ao século XIX, componentes de uma civilização filosófica que desloca o poder residente a transcendência para outorgá-lo às autoridades laicas e terrenas. Era contra este conjunto de forças contra os quais tão denodadamente o extremenho emprega os esforços de sua oposição intelectual ${ }^{47}$.

\footnotetext{
44 Donoso Cortés, J, Obras Completas..., op. cit., Tomo I, p. 325.

45 Donoso Cortés sublinha em uma de suas missivas ao diretor do jornal El Orden que o eu é o elemento constitutivo básico do satânico, que o próprio inferno encontra-se habitado por tão somente um pronome: eu (cfr. Donoso Cortés, Juan, “Sr. Director de El Orden", París, 10 de junio de 1851, em Obras de Don Juan Donoso Cortés, Casa Editorial de San Francisco de Sales, Madrid, 1904, pp. 350-354, p. 351). Em outros termos, que "[...] el yo es por su naturaleza satánico" (idem). Não encontra-se distanciada desta perspectiva a crítica donosiana de que o eu satânico está à base do liberalismo, sistema filosófico que propugna e eleva o valor do indivíduo sobre todos os demais fatores.

46 Cfr. Donoso Cortés, J., Ensayo..., op. cit., p. 252.

47 Cfr. Donoso Cortés, , J., “Carta al eminentísimo señor Cardenal Fornari...”, op. cit., p. 388.
} 
O nefasto caráter que Donoso Cortés reserva ao monismo revolucionário, até mesmo satânico, parece não observar estar contido em sua própria argumentação. Ao atacar toda a carga de males que o movimento revolucionário supostamente era capaz de engendrar no mundo, Donoso apresenta a estratégia de criar o inimigo e, passo seguinte, magnificizar a sua potência, agressiva assim como toda a sua disposição e energia para a comissão de feroz barbárie sangrenta por antonomásia. Este movimento inicial introduz a condição lógica para a concepção de um poder intenso que reclama magnanimidade, força suficiente, e sempre igualitariamente disponível para contrapor-se e vencer aos desarranjos sociopolíticos vetorializados pela dor que habita os mais recônditos sentimentos humanos. Este poder soberaníssimo haverá de agir valendo-se, não raro, e alegadamente de modo legítimo, com idêntica força e ferocidade, sob o pretexto da elisão do mal e da dor e conseqüente realização do bem no mundo. Donoso compreende que a comissão injusta do mal e da barbárie. Este soberano poder distingue o seu legítimo e justo uso conforme encontrese, ou não, inspirado nos mais castiços dogmas do catolicismo ${ }^{48}$.

Para Donoso Cortés está bastante claro que todas as vias societárias que configurem uma alternância ao catolicismo, e que, em verdade, não rumam senão para a consolidação do processo de instauração de todos os valores próprios das idades bárbaras ou, em suma, que "[...] donde no está el catolicismo, allí está la barbarie"49. A partir desta reflexão sobre o pulsante sentimento contrarrevolucionário de viés anticatólico, em Donoso Cortés é perceptível a intensidade com a qual reagirá a isto, transportando seus argumentos ao âmbito da teologia política.

Deste momento em diante, necessitamos ponderar o nível e a intensidade com que ocorre a recepção conceitual de Donoso por Schmitt assim como de que forma os instrumentalizou para realizar a sua construção teórica ${ }^{50}$. Esta conexão visa, em verdade, propiciar como a teoria do político e da democracia donosianas assim como da ditadura, mantém proximidade com a teoria jurídico-política de Schmitt. Esta é uma das análises que esta dissertação propõe-se desenvolver com vistas a melhor dimensionar o real impacto do pensamento conservador donosiano sobre Schmitt uma das vertentes do pensamento autoritário do século XX, sobre Schmitt, uma das ramificações do totalitarismo no século XXI**

48 Cfr. Donoso Cortés, J., Ensayo..., op. cit., p. 282.

49 Donoso Cortés, Juan, “Las Reformas de Pío IX”, em Textos Políticos, Rialp, Madrid, 1954, pp. 23-74, p. 59.

50 Quando Sснміт recorre ao pensamento político-teológico de Donoso Cortés parece-nos fazê-lo de modo a instrumentalizá-lo. Exemplo disto se dá quando ignora a crítica donosiana ao poder ilimitado (cfr. Donoso Cortés, Juan, "Respuesta a M. de Broglie”, em Textos Políticos, Rialp, Madrid, 1954, pp. 451-482, p. 463). De fato parece-nos que Donoso Cortés apenas deseja enfocar que o poder terreno deveria encontrar-se limitado à observância de princípios divinos. Isto sim, quando Schmitt realiza a leitura do político em Donoso parece-nos que retoma tão somente esta segunda ideia que remete o poder ilimitado na figura da divindade e sequer se dedica a tratar cientificamente a posição crítica de Donoso Cortés a respeito de um poder que, de ser ilimitado, se constitui em um ultraje ao poder divino, uma idolatria e, em suma, até mesmo à dignidade do homem (cfr. idem). A idolatria, como se sabe, aparece com rejeição desde distintas variantes do catolicismo mas, em Schmitt e as variantes totalitárias dentre as quais encontra-se o nacional-socialismo, desde logo, não há qualquer manifesto de rechaço senão de apoio e estímulo à idolatria das figuras de seus líderes.

*Artículo recibido: 15 de abril de 2012. Aceptado: 25 de junio de 2012. 


\section{Bibliografía}

Abelenda, Raúl Sánchez, La teoría del poder en el pensamiento político de Juan Donoso Cortés, Editorial Universitaria de Buenos Aires, Buenos Aires, 1969.

Balmes, Jaime, Obras Completas. Escritos Políticos, Tomo VI, B.A.C., Madrid, 1950.

BíBlia SAGRADA, tradução dos originais gregos, hebraico e aramaico mediante a versão dos Monges, 192ª ed., Ave Maria, São Paulo, 2010.

Corts Grau, José, "Perfil actual de Donoso Cortés", Revista de Estudios Políticos, Nos. 19-20, 1945, pp. 74-118, disponível em http://www.cepc.es/rap/Publicaciones/Revistas/2/REP_019-020_084.pdf. Acesso em 03 out. 2009.

De Maistre, Joseph, Maistre: Considerations on France, Cambridge University Press, Cambridge, 1994.

Dias, Romulddo, Imagens de ordem. A doutrina católica sobre autoridade no Brasil (1922-1933), Editora da Universidade Estadual Paulista, São Paulo, 1996.

Díez Del Corral, Luís, El liberalismo doctrinario, Centro de Estudios Constitucionales, Madrid, 1984.

Donoso Cortés, Juan, "Discurso sobre la dictadura", em Donoso Cortés, JuAn, Textos Políticos, Rialp, Madrid, 1954, pp. 77-106.

, “Las Reformas de Pío IX”, em Donoso Cortés, Juan, Textos Políticos, Rialp, Madrid, 1954, pp. 23-74.

----------------------, “Carta al Conde Raczynski”, Dresden, 23 de agosto de 1849, em Donoso Cortés, Juan, Textos Políticos, Rialp, Madrid, 1954, pp. 125-127.

, "Respuesta a M. de Broglie", em Donoso Cortés, Juan, Textos Políticos, Rialp, Madrid, 1954, pp. 451-482. 1946.

-, Obras Completas de Donoso Cortés, Tomo I, B.A.C., Madrid,

---------------------, Ensayo sobre el catolicismo, liberalismo y socialismo, Editorial Americalee, Buenos Aires, 1943.

, “Carta al Príncipe de Metternich”, París, 18 de mayo de 1852, em 
Donoso Cortés, Juan, Obras de Don Juan Donoso Cortés, dirección y prólogo de Don Juan Manuel Orti y Lara, Vol. II, Casa Editorial de San Francisco de Sales, Madrid, 1904, pp. 381-383.

, “Carta al eminentísimo señor Cardenal Fornari sobre el principio generador de los más graves errores de nuestros días", París, 19 de junio de 1852, em Donoso Cortés, Juan, Obras de Don Juan Donoso Cortés, dirección y prólogo de Don Juan Manuel Orti y Lara, Vol. II, Casa Editorial de San Francisco de Sales, Madrid, 1904, pp. 385-409.

, "Carta ao Director de la 'Revue des Deux Mondes", en refutación de un artículo de M. Alberto de Broglie, París, 15 de noviembre de 1852, em Donoso Cortés, Juan, Obras de Don Juan Donoso Cortés, dirección y prólogo de Don Juan Manuel Orti y Lara, Vol. II, Casa Editorial de San Francisco de Sales, Madrid, 1904, pp. 411-437.

-, "Sr. Director de El Orden", París, 10 de junio de 1851, em Donoso

Cortés, Juan, Obras de Don Juan Donoso Cortés, dirección y prólogo de Don Juan Manuel Orti y Lara, Vol. II, Casa Editorial de San Francisco de Sales, Madrid, 1904, pp. 350-354. Cortés, Juan, Obras de Don Juan Donoso Cortés, dirección y prólogo de Don Juan Manuel Orti y Lara, Vol. II, Casa Editorial de San Francisco de Sales, Madrid, 1904, pp. 476-480.

20 de julio de 1850, em Donoso Cortés, Juan, Obras de Don Juan Donoso Cortés, dirección y prólogo de Don Juan Manuel Orti y Lara. Vol. II, Casa Editorial de San Francisco de Sales, Madrid, 1904, pp. 328-330.

"Discurso sobre la situación general de Europa. Pronunciado en el Congreso el 30 de enero de 1850, al discutirse el proyecto de autorización al Gobierno para plantear los presupuestos de aquel año", em Donoso CoRTÉs, JuAn, Obras de Don Juan Donoso Cortés, dirección y prólogo de Don Juan Manuel Orti y Lara, Vol. II, Casa Editorial de San Francisco de Sales, Madrid, 1904, pp. 159-182.

greso el 30 de diciembre de 1850, al discutirse el proyecto de autorización al Gobierno para plantear los presupuestos del siguiente año, em Donoso Cortés, Juan, Obras de Don Juan Donoso Cortés, dirección y prólogo de Don Juan Manuel Orti y Lara, Vol. II, Casa Editorial de San Francisco de Sales, Madrid, 1904, pp. 183-214. 
-, "Polémica", publicado en El País y en El Heraldo, Berlín, 16 de julio de 1849, em Donoso Cortés, JuAn, Obras de Don Juan Donoso Cortés, dirección y prólogo de Don Juan Manuel Orti y Lara, Vol. II, Casa Editorial de San Francisco de Sales, Madrid, 1904, pp. 144-158.

Fornés Murciano, Antonio, "Providencialismo, decisionismo y pesimismo antropológico. Influencia de Joseph de Maistre en la teologia política de Donoso Cortés", Hispania Sacra, Vol. LXIII, 127, enero-junio, 2011, pp. 235-260.

Galindo Herrero, Santiago, "Donoso Cortés en su paralelo com Balmes y Pastor Díaz", Revista de Estudios Políticos, No. 69, 1953, pp. 111-140.

Garay Vera, Cristián, "Donoso Ultramontano o su militancia católica”, Fundación Elías de Tejada, Año XVI, 2010, pp. 147-160, disponível em http://www.fundacioneliasdetejada.org/Documentacion/Anales/PDF\%20ANALES\%2016/ANA16-P-147-160.pdf. Acessado em 12. Mar. 2011.

González Cuevas, Pedro Carlos, El pensamiento politico de la derecha española en el siglo XX. De la crisis de la Restauración al Estado de partidos (1898-2000), Tecnos, Madrid, 2005.

Guarnieri, Carlo, “Cesarismo”, em Bobbio, Norberto, Matteucci, Nicola, e Pasquino, Gianfranco, Dicionário de Política, Vol. 1, 11a ed., UnB, Brasília, 1998, pp. 159-162.

Habermas, Jürgen e Ratzinger, Joseph, Dialética da Secularização. Sobre razão e religião, organização e prefácio de Florian Schüller, $3^{\text {a }}$ Edição, Idéias \& Letras, Aparecida, SP, 2007.

JimÉnez, PABLo, "La reacción contra la historia: Donoso Cortés y Carl Schmitt", Nuevas tendencias historiográficas e historia local en España: actas del II Congreso de Historia Local de Aragón (Huesca, 7 al 9 de julio de 1999), coord. por Miguel Angel Ruiz Carnicer y Carmen Frías Corredor, 2001, pp. 401-416, disponível em http://dialnet.unirioja.es/servlet/busquedadoc? $\mathrm{db}=1 \& \mathrm{t}=\mathrm{La}+$ reacci $\% \mathrm{C} 3 \% \mathrm{~B} 3 \mathrm{n}+$ contra + la + historia. + Don oso + Cort $\%$ C3\%A9s + y + Carl+Schmitt\&td=todo. Acesso em 10.Nov.2010.

KierkegaArd, SöRen, O conceito de ironia, Vozes, Petrópolis, 1991.

Macías López, Joaquín, "Balmes y Donoso Cortés ante la política española en el siglo XIX”, El Catoblepas, No. 105, noviembre, 2010, pp. 1-14, disponível em http://nodulo. org/ec/2010/n105p14.htm. Acessado em 27 de abril de 2011.

López Medina, Emilio, “Balmes: La opción realista”, Actas del IV Congreso Internacional 
de la S.I.T.A., Tomo III, Comunicaciones, Publicaciones Obra Social y Cultural Cajasur, Córdoba, 1999, pp. 1485-1491.

Martínez-Sicluna, Consuelo, "Donoso Cortés: La cuestión vital de España", Anales de la Fundación Elías de Tejada, Año XVI, 2010, pp. 161-169, disponível em http:// www.fundacioneliasdetejada.org/Documentacion/Anales/PDF\%20ANALES\%2016/ ANA16-P-161-169.pdf. Acessado em 20 de setembro de 2011.

Menczer, B., "Metternich y Donoso Cortés. Pensamiento cristiano y conservador en la revolución europea", Arbor, Vol. 13, 1949, pp. 63-92.

Menéndez Pelayo, Marcelino, Historia de los heterodoxos españoles, $4^{\mathrm{a}}$ ed., II tomos, B.A.C., Madrid, 1987.

de crítica filosófica, Aldus, Santander, 1948.

Miyazaki, Yusuke, "Responsibility of making decisions without decisionism: From Carl Schmitt to Jacques Derrida", em TaKashi, Kurihara (ed.), Glauben und Wissen in der Geistesgeschichte, Graduate School of Modern Society and Culture, Niigata University, Niigata, 2011, pp. 140-155.

Pavani, Roney Marcos, Repensando o conservadorismo católico: política, religião e história em Juan Donoso Cortés, Dissertação de Mestrado em História Social das Relações Políticas, Dissertação apresentada no Centro de Ciências Humanas e Naturais do Programa de Pós-Graduação em História da Universidade Federal do Espírito Santo, 2010, disponível em http://www.ufes.br/ppghis/Documentos/2008/Roney\%20Marcos\%20Pavani-\%20Turma \%202008\%20DEFESA.pdf. Acesso em 15.Mar.2011.

Pellistrandi, Benoît, "Catolicismo e identidad nacional en España en el siglo XIX: un discurso histórico de Donoso Cortés a Menéndez Pelayo", Religión y Sociedad en España: (siglos XIX y XX): Seminario celebrado en la Casa de Velázquez (1994-1995), coord. por Paul Aubert, 2002, pp. 91-120.

Perfecto García, Miguel Ángel, “O pensamento antiliberal espanhol: intelectuais e políticos antiliberais na Espanha do primeiro terço do século XX”, em LimOnCic, FLÁvio, e Martinho, Francisco Carlos Palomanes (org.), Os intelectuais do antiliberalismo. Projetos e políticas para outras modernidades, Civilização Brasileira, Rio de Janeiro, 2010, pp. 439-476.

Prieto Escudero, Germán, "Balmes o la prioridad de lo sociorreligioso sobre lo políticoeconómico", Revista de Estudios Políticos, No. 182, 1972, pp. 159-180. 
Reig TApia, Alberto, "Aproximación a la teoría del caudillaje en Francisco Javier Conde", Revista de Estudios Políticos (Nueva Época), Núm. 69, julio-septiembre, 1990, pp. 61-81.

RocA, Dionisio, "Humanismo, progreso y trascendencia en el pensamiento balmesiano", Actas del IV Congreso Internacional de la S.I.T.A., Tomo IV, Comunicaciones, Publicaciones Obra Social y Cultural Cajasur, Córdoba, 1999, pp. 1949-1957.

Rodríguez Caamaño, Manuel, "Presentación. Jaime Balmes y las Ciencias Sociales", Reis. Revista Española de Investigaciones Sociológicas, No. 82, 1998, pp. 285-290.

Romano, Roberto, Brasil: Igreja contra Estado, Kairós, São Paulo, 1979.

Schramm, Edmund, Donoso Cortés, ejemplo del pensamiento de la tradición. Colección O Crece o Muere, no. 28, 2a edición, Ryvadeneira, Madrid, 1961.

Schmitt, Carl, Römischer Katholizismus und politische Form, Klein-Cotta, Stuttgart, 2008.

, Interpretación Europea de Donoso Cortés, Struhart, Buenos Aires, 2006.

, "Interpretación Europea de Donoso Cortés", em Aguilar, Héctor OresTES, Carl Schmitt, Teólogo de la política, Fondo de Cultura Económica, México, 2001, pp. 227-243.

, Catolicismo Romano y forma política, Tecnos, Madrid, 2000.

, Catolicismo Romano e forma política, tradução, notas e apresentação de Alexandre Franco de Sá, 1ª ed., Hugin Editores, Lisboa, 1998.

---------------, La defensa de la Constitución, Tecnos, Madrid, 1998.

, A crise da democracia parlamentar, Scritta, São Paulo, 1996.

----------------, Teoría de la Constitución, Alianza, Madrid, 1992.

, Donoso Cortés. Su posición en la Historia de la Filosofía del Estado Europeo. Conferencias dadas en el Centro de Intercambio Internacional Germanoespañol, Madrid, [s.n.], 1930.

URigüEn, Begoña, Orígenes y evolución de la derecha española: el neo-catolicismo, Centro de Estudios Historicos / C.S.I.C., Madrid, 1986. 
Ullate, José Antoni, "La evolución truncada de Donoso Cortés", Anales de la Fundación Elías de Tejada, Año XVI, 2010, pp. 171-179, disponível em http://www.fundacioneliasdetejada.org/Documentacion/Anales/PDF\%20ANALES\%2016/ANA16P-161-169.pdf. Acessado em 20 de setembro de 2011.

Val Merino, F. A. Del, "Los fundamentos ideológicos de la teoría de la Dictadura de Donoso Cortés", Cuadernos de Realidades Sociales, 1979, 14-15, pp. 213-220.

Valmy, Duque De, “Al Sr. Donoso”, París, 22 de septiembre de 1850, em Donoso Cortés, JuAn, Obras de Don Juan Donoso Cortés, dirección y prólogo de Don Juan Manuel Orti y Lara, Vol. II, Casa Editorial de San Francisco de Sales, Madrid, 1904, pp. 331-333.

Villar Borda, Luis, Donoso Cortés y Carl Schmitt, Universidad Externado de Colombia, Bogotá, 2006. 